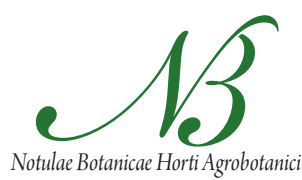

Cluj-Napoca

\title{
Occurrence of Cucumber mosaic virus Infecting Parsley (Petroselinum crispum) in Turkey
}

\author{
Mehmet A.SEVIK, Cemile AKCURA \\ University of Ondokuz Mayis, Faculty of Agriculture,Department of Plant Protection, Samsun, Turkey; malis@omu.edu.tr
}

\begin{abstract}
Parsley plants are grown throughout Turkey as summer and winter crops. Diseased plants having typical of a virus infection such as mosaic, mottling, and leaf distortion symptoms were frequently observed in most of the parsley fields and vegetable public markets in the Middle Black Sea Region of Turkey in 2010. Using double-antibody sandwich enzyme-linked immunosorbent assay (DAS-ELISA), Cucumber mosaic virus (CMV) was detected on the diseased parsley plants. However, using farmers and commercial seed lots, CMV was not detected in seeds or germinating seedlings.
\end{abstract}

Keywords: CMV, parsley, seed transmission

\section{Introduction}

Parsley (Petroselinum crispum), a member of the Apiaceae family, was used principally as a medicinal plant until the Middle Ages, but recently it has become an important aromatic plant and to a lesser extent a vegetable crop (Marthe et al., 2003). Parsley is a bright green biennial herb and marketed continuously throughout the year, often used as spice and a fresh market culinary green. Parsley was originally native to southern Europe and the eastern Mediterranean region. Today it is cultivated widely in Turkey for its leaves, seeds and roots. Traditionally, cultivation takes place in house gardens, but some specialized companies now intensify the parsley production to meet broader market demands (Marthe et al., 2003).

The Black Sea Region of Turkey is a major parsley production zone, where 400 ha of parsley was grown in Samsun city alone in 2010, with an estimated fresh market production of 400 tons (Data of The Ministry of Agriculture and Rural Affairs). The yield potential of such crop in the region was limited by a number of diseases. Parsley may be attacked by fungal and bacterial diseases (Cerkauskas, 1991; Kurt, 2003; Marthe et al., 2003; Tok, 2008) and by several viruses (Marthe et al., 2003), including Celery mosaic virus (CeMV), Apium virus $Y$ (ApVY), Strawberry latent ringspot virus (SLRV), Parsley latent virus (PILV), Broad bean wilt virus (BBWV), Carrot mottle virus (CMotV) and Cucumber mosaic virus (CMV) (Frowd and Tomlinson, 1972; Bos et al., 1979; Van Dijk and Bos, 1989; Bellardi and Bertaccini, 1991; Anonymous, 1999; Marthe et al., 2003; Houliara et al., 2006; Tian et al., 2008; Mahy and van Regenmortel, 2009). Frequently, CMV and CeMV were the most prevalent viruses on parsley in several regions (Bos et al., 1979).
Cucumber mosaic virus (CMV) (genus Cucumovirus, family Bromoviridae) is one of the most economically important viruses causing diseases in more than 1.000 botanical species (belonging to 100 families) (van Regenmortel et al., 2000). CMV is transmitted by aphids (about 75 species) in a non-persistent manner and also could be seed-borne in different host plants. The present study was carried out to access the occurrence of CMV on parsley in the Middle Black Sea Region of Turkey and its effects on the fresh market production of parsley.

\section{Materials and methods}

\section{Survey}

Parsley leaf samples were collected during 2010 from different fields in parsley-growing areas and vegetable public markets of Samsun city located in the Middle Black Sea Region of Turkey (Fig. 1). In each area, plants were randomly evaluated for virus-like symptoms such as mosaic, mottling, vein clearing, puckering and leaf malformation.

\section{Seed collections}

Parsley seeds were also collected from farmer and commercial lots to test for the presence of CMV. In seedling grow-out assays, five replicates of 100 seeds of each lot were planted in flats in climatic chamber to determine percentage of virus transmission (Ling, 2010). Testing was of dry seeds and seeds germinated on moist filter paper in Petri dishes in a climatic chamber $\left(23^{\circ} \mathrm{C}, 16 \mathrm{~h}\right.$ light $/ 8 \mathrm{~h}$ dark, $80 \% \mathrm{RH}$ ) for 7 days (Fig. 2). Seeds or seedlings were tested by grinding whole seeds or leaf samples in a mortar with extraction buffer (PBS: $0.13 \mathrm{M} \mathrm{NaCl}, 0.014 \mathrm{M}$ $\left.\mathrm{KH}_{2} \mathrm{PO}_{4} 0.08 \mathrm{M} \mathrm{Na}_{2} \mathrm{HPO}_{4}, 0.002 \mathrm{M} \mathrm{KCl}, \mathrm{pH} 7.4\right)$ containing 0.05\% Tween-20 (Bos et al., 1979). 


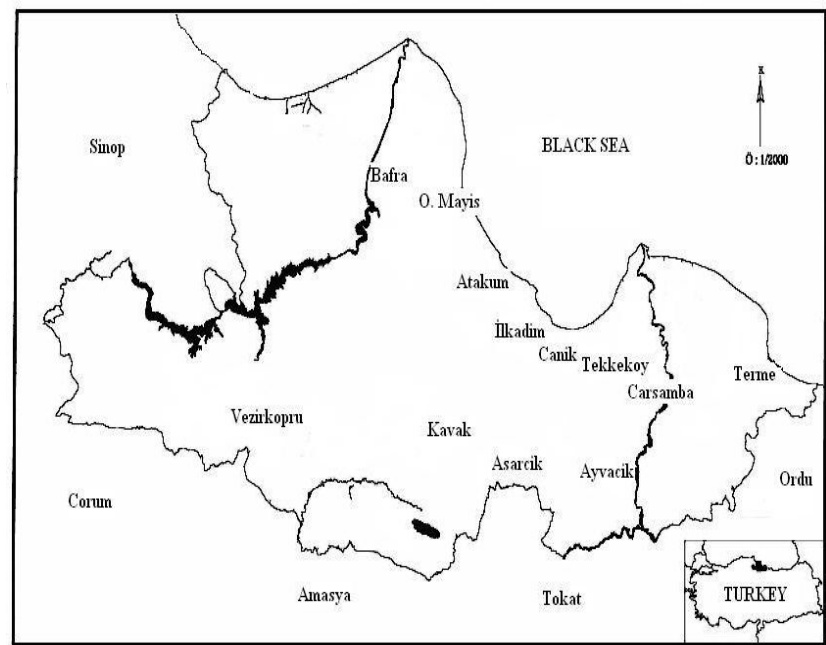

Fig. 1. Map of the Middle Black Sea Region of Turkey showing surveyed areas

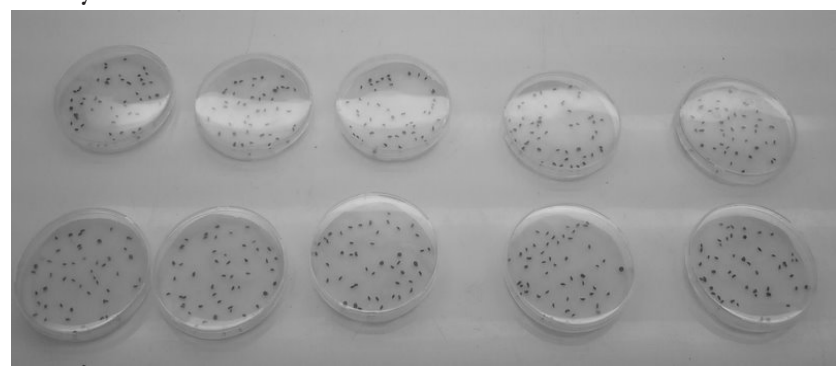

Fig. 2. Parsley seeds were placed in Petri dishes with filtration papers

\section{Serology}

Collected leaf tissue and seed samples were tested for the presence of CMV using double antibody sandwichenzyme linked immunosorbent assay (DAS-ELISA) protocol as reported previously by Clark and Adams (1977) following the manufacturer's instructions (Bioreba, Switzerland). Briefly, leaf tissues or seed samples were ground (1:5 wt/vol) in extraction buffer (PBS: $0.13 \mathrm{M} \mathrm{NaCl}$, $0.014 \mathrm{M} \mathrm{KH}_{2} \mathrm{PO}_{4} 0.08 \mathrm{M} \mathrm{Na}_{2} \mathrm{HPO}_{4}, 0.002 \mathrm{M} \mathrm{KCl}, \mathrm{pH}$ 7.4 ) containing $0.05 \%$ Tween-20 and $100 \mathrm{ul}$ was added to wells of a microplate previously coated with CMV-specific polyclonal antiserum. After washing, alkaline phosphatase conjugated antibody was added and incubated for $4 \mathrm{~h}$ at $37^{\circ} \mathrm{C}$. Finally, p-nitrophenyl phosphate (Sigma) in diethanolamine substrate buffer $(0.5 \mathrm{mg} / \mathrm{ml} ; \mathrm{pH}: 9.8)$ was added to wells and incubated at room temperature for 30 $180 \mathrm{~min}$. Absorbance values were read at $405 \mathrm{~nm}$ using a microplate reader (Tecan, Spectra). Extraction buffers were used as negative controls. Samples were considered to be positive when the absorbance values at $405 \mathrm{~nm}\left(\mathrm{~A}_{405}\right)$ values exceeded the mean of the negative controls by least a factor of three (Fletcher, 2001).

\section{Results and discussion}

During this survey, the virus causing mosaic, mottling, vein clearing, puckering and leaf malformation and yield losses were encountered (Fig. 3). Leaf mosaic, puckering symptoms ranged from $5 \%$ up to $10 \%$ of the crops surveyed and per bunch parsley collected from vegetable public markets. Infected plants were determined visually by symptoms in the parsley leaves.

Based on DAS-ELISA tests, CMV was detected in parsley leaf samples in Turkey. CMV was found in 6\% of the areas surveyed, whereas CMV was detected in $70 \%$ of the symptomatic parsley plants tested. Tests were conducted using several negative controls for the virus. Therefore, the range of absorbance values of negative controls varied from 0.068 to 0.085 . Positive samples gave absorbance values of 0.453 to 0.744 for $2 \mathrm{~h}$ (Tab. 1 ).

In the serial tests of several commercial seed and seeds collected from farmers tested for CMV, but the virus could not be detected in any dry or germinated seeds. The virus could neither be detected in 5 groups of 100 dry parsley seeds, nor in 5 groups of 100 germinated seeds. Testing of seedlings grown in flats in the climatic chamber resulted in negative reactions with all 5 groups of 100 seedlings tested.

Parsley crop is attacked by a number of viruses; CeMV, ApVY, SLRV, PILV, BBWV, CMotV and CMV. However CMV and CeMV were the most prevalent viruses in some regions (Bos et al., 1979). Our results indicate CMV is partially prevalent virus in the region. Similar findings reported previously in different countries by several researchers. In Greece, the neighbour country of Turkey, in 2002-2004, a survey was carried out to determine virus incidence in parsley crops showing virus-like symptoms, such as mosaic, yellowing, stunting and leaf distortion. A total of 221 parsley (Petroselinum crispum) samples from three different prefectures of Greece were collected. Virus diagnosis was carried out by ELISA, using polyclonal antisera against several viruses. Parsley samples were infected by ApVY (64.3\%), followed by CMV (6.8\%) and CeMV (3.6\%) (Houliara et al., 2006).

In Germany, CMV and CeMV were the most prevalent ones, whereas in Britain $\mathrm{CMotV}$ was the most frequently isolated virus (Bos et al., 1979). Severe stunting of parsley plants, with leaf chlorosis and reddening was reported from four localities in Britain in 1968-70. Affected plants were collected from thirteen sites in Bedfordshire, Buckinghamshire, Cheshire and Bristol, and five viruses (designated PV1-PV5) were isolated from them. The viruses

Tab. 1. Range of absorbance values of negative controls, and positive and negative samples

\begin{tabular}{cccc}
\hline \multicolumn{4}{c}{ Absorbance values } \\
\hline Plant, virus $^{\mathrm{a}}$ & $\begin{array}{c}\text { Negative } \\
\text { controls }\end{array}$ & $\begin{array}{c}\text { CMV-negative } \\
\text { samples }\end{array}$ & $\begin{array}{c}\text { CMV-positive } \\
\text { samples }\end{array}$ \\
\hline Parsley, CMV & & & \\
\hline Leaf samples & $0.065-0.085$ & $0.270-0.384$ & $0.453-0.744$ \\
Seed samples & $0.066-0.079$ & $0.176-0.363$ & - \\
\hline
\end{tabular}


32

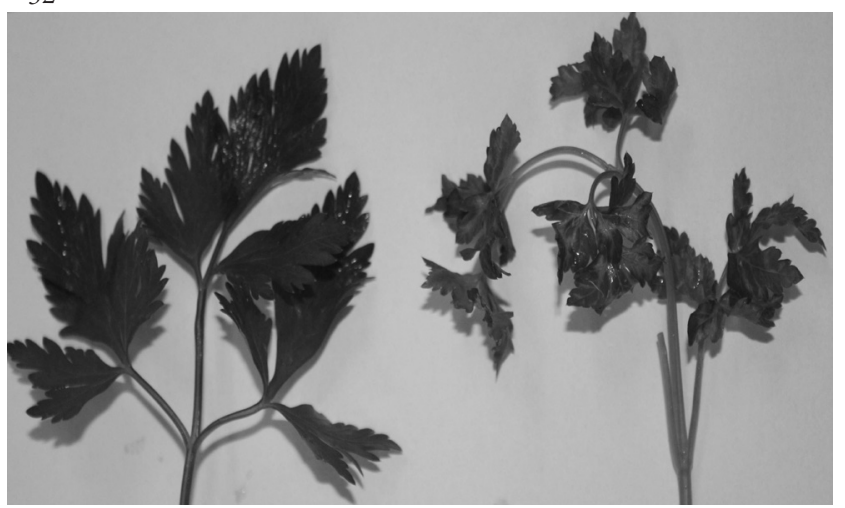

Fig. 3. Symptom associated with natural infection by CMV in parsley (right) and healthy (left)

were distinguished by electron microscopy, host range and type of aphid transmission. The viruses were identified serologically as Carrot mottle virus (CMotV), Celery mosaic virus, Cucumber mosaic virus and Broad bean wilt virus, respectively. PV5 was not fully identified by Frowd and Tomlinson (1972).

Parsley plants were moderately or strongly infected by other viruses, mainly CeMV (Marthe et al., 2003). Recently, Apium virus Y (ApVY) was detected in field-grown parsley (Petroselinum crispum) in California. In 2003, cilantro plants growing in three different fields in California (Monterey, San Joaquin, and San Luis Obispo counties) expressed symptoms of mosaic, vein clearing, and stunting (Tian et al., 2008).

CMV was originally isolated from parsley in Florida, USA (Sherf and MacNab, 1986) and in the Netherlands (Van Dijk and Bos, 1989). Under natural conditions, CMV generally is transmitted by aphids, but the virus also has been transmitted by seed in some plant species (Neergard, 1977). Bos et al. (1979) reported that CMV and especially Tomato black ring virus might pass via parsley seed because of their known seed transmission in other hosts, but the virus was not detected in parsley seed samples in the current study. In contrast to our findings, PILV was isolated from 38 out of 54 samples of seed of parsley of 17 out of 24 cultivars and from all five European countries tested, but not from some samples from the USA. It could easily be detected in seedlings and also in seeds germinated on moist filter paper, but not in dry seeds or in seeds soaked in water (Bos et al., 1979).

Although, in recent field studies (Tok and Kurt, 2004), other fungal pathogens were observed to attack parsley severely, particularly Septoria petroselini Desm. in Hatay province of Turkey. So far, there is no data on the incidence and distribution of viruses in field-grown parsley plants in Turkey. In the present study, a significant percentage of samples from symptomatic plants analyzed did not react with the antiserum against CMV. The rest of leaf samples were possibly infected with other parsley viruses of which antisera were not available in the current study.
Additional research is needed to investigate the other viruses on parsley.

Finally, field-grown parsley crop production is mainly affected by the CMV in the region and our data provide essential basic information for the future introduction of parsley virus control strategies in Turkey. So far virus diseases have not been reported on parsley in Turkey. To our knowledge, this is the first report of CMV on parsley in Turkey.

\section{Acknowledgements}

We thank Ondokuz Mayis University Research Fund and Faculty of Agriculture for supporting this research.

\section{References}

Anonymous (1999). Mosaic diseases of cucurbits. Report on Plant Disease. RPD No. 926 November, Depart. of Crop Sciences, University of Illinois at Urbana-Champaign, 1-9.

Bellardi MG, Bertaccini A (1991). Parsley seeds infected by Strawberry latent ringspot virus (SLRV). Phytopath 30:198199.

Bos L, Huttınga H, Maat DZ (1979). Parsley latent virus, a new and prevalent seed-transmitted, but possibly harmless virus of Petroselinum crispum. Neth JPI Path 85:125-136.

Cerkauskas RF (1991) Susceptibility of parsley cultivars to Septoria blight. Can J Plant Pathol 13:273.

Clark MF, Adams AN (1997) Characteristics of the microplate method of enzyme linked immunosorbent assay for the detection of plant viruses. J Genl Virol 34:475-483.

Fletcher JD (2001). New hosts of Alfalfa mosaic virus, Cucumber mosaic virus, Potato virus $Y$, Soybean dwarf virus, and Tomato spotted wilt virus in New Zealand. NZJ Crop Hortic Sci 29: 213-217.

Frowd JA, Tomlinson JA (1972). The isolation and identification of parsley viruses occurring in Britain. Ann App Biol 72:177188.

Houliara M, Maliogka V, Dovas CI, Efthimiou K, Papathanasiou K, Sereti A, Harou A, Katis NI (2006). Incidence and characterization of viruses infecting cultivated species of the family Apiaceae in Greece. Phytopath Mediterr 45:163200.

Kurt S (2003). First report of Septoria blight of parsley caused by Septoria petroselini in the Mediterranean Region of Turkey. Plant Dis 87:99.

Ling KS (2010). Effectiveness of chemo- and thermotherapeutic treatments on Pepino mosaic virus in tomato seed. Plant Dis 94:325-328.

Mahy BWJ, van Regenmortel MHV (2009). Desk Encyclopedia of Plant and Fungal Virology.

Marthe F, Scholze P, Kramer R, Proll E, Hammer K (2003). Evaluation of parsley for resistance to the pathogens Alternaria radicina, Erysiphe heraclei, Fusarium oxysporum and Celery mosaic virus (CeMV). Plant Breed 122:248-255. 
Neegaard P (1977). Survey of seed-borne viruses. p. 80-116. In: Seed Pathology. John Wiley and Sons, New York.

Sherf AF, MacNab AA (1986). Vegetable diseases and their control, John Wiley and Sons, 605 Third Ave., New York NY, p. 728.

Tian T, Liu HY, Koike ST (2008). First report of Apium virus $Y$ on cilantro, celery, and parsley in California. Plant Dis 92:1254.

Tok FM, Kurt M (2004). Incidence and prevalence of Septoria blight in parsley growing areas of Hatay province. Proceedings of the First Plant Protection Congress of Turkey. 8-10 September 2004, Samsun, Turkey. 191.
Tok FM (2008). Chemical control of Septoria blight of parsley caused by Septoria petroselini. Turk J Agric For 32:487-494.

Van Dijk P, Bos L (1989). Survey and biological differentiation of viruses of wild and cultivated Umbelliferae in the Netherlands. Neth J P1 Path 95:1-34.

Van Regenmortel MHV, Fauquet CM, Bishop DHL, Carstens EB, Estes MK, Lemon SM, ManiloffJ, Mayo MA, McGeoch DJ, Pringle CR, Wickne RB (2000). Virus Taxonomy Classification and Nomenclature of Viruses. Academic Press, S. Diego. 